\title{
"That's Where They Knew Me When": Oklahoma Senior Follies and the Narrative of Decline
}

For two years I served as musical director and arranger for a musical revue, consisting entirely of performers over the age of fifty-five, known as the Oklahoma Senior Follies. As part of the much larger Senior Follies movement, the Oklahoma Senior Follies makes a place on the musical stage for aging musical theater performers. I experienced up close the remarkable local talent represented by the cast members and likewise witnessed the importance of having an opportunity to express one's voice in all stages of life.

Yet the ageist conditions that necessitate a theater like the Senior Follies call for a complicated response. Inasmuch as the Oklahoma Senior Follies attempts to reframe aging as positive, performers frequently resort to the same ageist stereotypes they hoped to frustrate. I see this complicated response to conventional narratives of aging arising from a conflict between the musical format of the follies and constraints effected by the local theater industry. I use my experience with and proximity to the Oklahoma Senior Follies to construct a case study that gives explicit attention to how seniors have attempted to resist marginalization through performance. I examine the effects of the Senior Follies

Jake Johnson is a doctoral student in musicology at UCLA, where he is completing a dissertation on the relationship between Mormons and American musical theater. His research has appeared or is forthcoming in the Journal of the Society for American Music, Tempo, Echo: A Music-Centered Journal, This Land, The Oxford Handbook of Voice Studies, and The Oxford Handbook of Hip Hop Music Studies, among others. Jake is also a highly sought after collaborative pianist and vocal coach, having served on vocal coaching and accompanying faculties at Oklahoma City University, DePaul University, and the Hawaii Performing Arts Festival. He now lives in Los Angeles with his wife, two children, and their standard poodle named Alice. 
movement in Oklahoma City and also bring into relief what I perceive to be problems in the way the musical theater industry marginalizes the aging.

\section{Aging and Musical Theater}

Musicals notoriously tell stories of redemption or of overcoming seemingly impossible odds, and the genre's treatment of age seems, at least in notable cases, to fit within this narrative. Stephen Sondheim's Follies (1971), for instance, moralizes the theme of second chances and buoys an indefatigable refrain in Carlotta Campion's torch song "I'm Still Here." Fans allow space for doyennes like Elaine Stritch and Bea Arthur to work into old age under the allowances of divahood. ${ }^{1}$ Until a few years ago, Ted Neeley continued to spellbind audiences as the title character in Jesus Christ Superstar (1971), never mind that his aging body and voice betrayed any sense of resemblance to the thirty-three-year-old martyr. ${ }^{2}$ Renowned librettist Fred Ebb was working on the new musical Curtains when he died. He was seventy-six.

Yet these are exceptions that prove the rule. Despite the prominence of well-known and senescent characters like Mother Superior in The Sound of Music and Henry Higgins in My Fair Lady, most performers today find their careers curtailed by the musical theater industry's limitations on meaningful avenues for the aging performer. A Broadway star has little room to evolve over the course of her career because the industry favors the young; even lateral moves are limited. Particularly in popular dance musicals like West Side Story, Guys and Dolls, Grease, and 42nd Street, where almost all performers have to dance at some point, lead characters must of necessity be around the same young age. Even more, the grueling schedule of eight shows a week certainly makes a career on Broadway hazardous and largely unfit even for the most disciplined (and youthful) bodies. The intense physical requirements for a Reno Sweeney in Anything Goes, for example, crimps performance possibilities beyond a certain phase of life. Musical theater's tendency to look past aging performers further positions musicals as reflections of mainstream societal practices that also marginalize those growing older. Raymond Knapp has recently argued along these lines regarding other marginalized populations, writing that "commercial calculation, standards of believability, and the dynamics of assimilation" have all "reinforced the dominance of the mainstream in musicals." 3 This realization comes despite the genre's reputation for problematizing cultural and societal norms. ${ }^{4}$ Musical theater thus stands distinct as a sometimes-progressive space where depictions or presentations of the elderly onstage, as with other frequent tokens of marginalization like race or gender, nonetheless reaffirm mainstream sensibilities. 
These mainstream sensibilities affirm a particularly distorted image of aging. Like other forms of popular culture, the Broadway musical contributes to a presumed connection between aging and deterioration, what cultural critic Margaret Morganroth Gullette in her book Aged by Culture aptly describes as the "master narrative of decline." ${ }^{5}$ This decline narrative is apparent in musical theater's penchant for younger characters, exaggerated and unfair categorization of aging characters as senile or decrepit, more instances of older characters being portrayed by younger actors, and fewer meaningful roles onstage for the aging population. Consider these few examples: In the musical Grey Gardens (2006), the old woman and her daughter are both played by young actresses who alternate roles midway through the show. Madame Armfeldt, mother to Desiree in Sondheim's A Little Night Music (1973), remains haughty and pitifully archaic in her wheelchair; she even falls asleep before she can finish singing her featured solo, "Liaisons," her thwarted singing perhaps musical theater's most damning signifier of social insignificance. In Pippin (1972), Pippin's grandmother urges her grandson to take advantage of life while he has the chance, "'cause spring will turn to fall in just no time at all." In these and many other instances, decline is implied in musical theater as an absolute condition of aging. If this is the case on the musical stage, where stage magic and convention resolve even the most implausible of dilemmas, then musical theater may be one of the cruelest spaces for the aging population to inhabit.

Yet from that cruel feature of musical theater has surfaced a form of entertainment designed to make room for older audiences and performers. In 1988 the first production of what would be known as the Anderson Senior Follies took place in Anderson, South Carolina. Nearly thirty years later, this annual musical production continues to entertain audiences throughout the region, providing, in the words of director Annette Martin, "a shot in the arm" for the local aging population. ${ }^{6}$ Since then, the Senior Follies has become a veritable movement, with productions opening and closing over the years in communities as diverse as Palm Springs, California; Dallas, Texas; Rockford, Illinois; and, most recently, Oklahoma City, Oklahoma. While each rendition of the Senior Follies is unique, all feature aging performers who put on a musical variety show. The movement's reach is remarkable: The Fabulous Palm Springs Follies played for twenty-three seasons for audiences totaling over four million. In 1997 the group was even the subject of a documentary appropriately titled Still Kicking: The Fabulous Palm Springs Follies.7

The Senior Follies cuts across the traditions of musical theater to create a vaudevillian escapade that uses farce and mockery to complicate this narrative of decline. Yet Bobbie Burbridge Lane, founder of the Oklahoma Senior Follies, still understands the movement as making a statement about hope and individual worth. She described the Senior Follies as 
"a movement to make seniors' lives very valuable and not to be thrown away, to sit in a chair and watch TV, be depressed, be worthless." It is "something to make it the best [period] of their life." 8 The purpose of the Senior Follies is not only to engage the narrative of decline but also to challenge the conventions of musical theater that for so long have coupled aging with disability or, more commonly, with invisibility. "You've got to feel like you still have value," said one Senior Follies cast member, "and that's what this does."

\section{The Performance of Decline}

In his book Staging Ageing: Theatre, Performance and the Narrative of Decline, Michael Mangan offers the following description of the master narrative of decline: "Broadly speaking, the master narrative of decline is that invisible but dominant cultural 'message' which encourages men and women to experience and articulate growing older essentially in terms of loss, isolation, and diminished physical, mental and material resources." 10 The narrative permeates so deeply into popular culture that its presence often goes undetected. Recent studies, however, suggest that the reality of this narrative is becoming more apparent. According to one watch group, "in 2005, the number of people age 65 and older had risen to 12.7 percent of the American population," though "elders were represented in less than 2 percent of programs on prime-time television." "Nothing could convey the low status of elders in our society better than their invisibility," the study concludes. ${ }^{11}$ Even in recent films that highlight life within the aging population, such as The Best Exotic Marigold Hotel (2011) and Quartet (2012), the fresh look into elderly life disguises the means by which those depictions are made. "Of course, there's a lovely wrinkle implied in pop-culture examples of the elderly," writes Lisa Kennedy. "Although growing older themselves, the actors are gainfully employed, still doing what they presumably love. How enviable. In doing the work of acting they defy the very thing they may also be representing: decline." 12

Recent scholarship attempts to turn this ageist narrative on its head by situating the decline narrative as a cultural assumption that bears little resemblance to normative aging processes. Advocating what she terms "aging-in-culture," Gullette argues, "We are aged more by culture than by chromosomes." ${ }^{13}$ She also acknowledges the pernicious staying power of the decline narrative, writing that it is "as hard to contain as dye. Once it has tinged our expectations of the future (sensations, rewards, status, power, voice) with peril, it tends to stain our experiences, our views of others, our explanatory systems, and then our retrospective judgments." 14 Although the decline narrative is often concealed, its presence in popular culture challenges normative aging processes and 
exaggerates aging to seem grossly debilitating. "At the level of ideology," adds Mangan, "our experience of aging is also determined by the ways in which our culture constructs the very concept of old age: by the kinds of spoken and unspoken assumptions and messages that circulate about what old age 'is,' and, most importantly, by the ways in which we internalize such messages." ${ }^{15}$ All this together means that the social construction of age and the ideology surrounding the aging process make the prospect of aging positively all the more troublesome.

That notwithstanding, Gullette and Mangan both suggest the power of resistance that lies within the large aging population. Speaking of the challenges inherit in a society that believes there to be an association between age and enfeeblement, Gullette writes that "there is a way out if one recognizes that decline is an ideology, learns more about its techniques, and invents resistances." ${ }^{16}$ Mangan shrewdly points out that "resistance and transgressiveness are most easily and frequently associated with adolescence and young adulthood," which are life stages notably categorized by anthropologist Victor Turner as occupying a liminal space relative to society. ${ }^{17}$ Yet Mangan troubles these categorical norms, wondering how such liminality could also be "reappropriated for the in-between-ness of old age."18

Empowering the aging therefore requires a repertoire of resistance, and opportunities for enacting that resistance are manifest in various social performances. These performances often are built from a platform of ageism, or instances of injustice erupting explicitly from conditions of aging. Varied attempts to reconcile negative stereotypes are indicative of ageism's reach; in attempting to correct ageist mindsets, often these performances of resistance likewise fail to escape ageist tendencies.

This is a potential hazard in almost every fight of marginalized populations. At a certain point, the necessary scaffolding erected to topple towers of injustice threatens to become a stronghold of ridicule itself. As with the well-known honorific "the greatest generation" popularized in the late 1990s by senior NBC newscaster Tom Brokaw, the Senior Follies movement has at times overreached ageism-correction in promoting old age at the expense of those in other age populations. Indeed, it has proven difficult to validate the aging population without essentializing old age as superior to other life stages. In speaking about her Anderson Senior Follies, for example, director Annette Martin calls attention to the eminence of childrearing practices of previous generations as contributing grit to the senior population: "The great part about working with seniors is they'll give everything a try. They're going to give it their best shot because they were raised that way. They were raised to not give any excuses-just do it." ${ }^{19}$ All Senior Follies productions also limit participants based on age, inviting only those fifty-five or older to join. Using the kind of dramatized rhetoric Martin employed above and 
discriminating participation based solely on age are obvious examples of ageism that, under other circumstances, might appear more pronounced and insidious. Efforts of the marginalized to regain voice can be messy affairs, and in this regard the Senior Follies is no exception.

Almost all of the performers I worked with had found their age a deterrent in getting cast in local productions and were happy to find a venue to perform in and an appreciative audience to entertain. Of the few who were still active performers onstage, the quality and type of parts available to them had dwindled to what many considered unmeaningful roles. The majority of the cast saw the Oklahoma Senior Follies as a playful opportunity to exhibit positive aspects of growing older and, for some, a chance to reclaim the role of musical theater performer. However, this eagerness to put age on display, coupled with the slapstick format of the show described below, often resulted in ageist stereotypes being aggressively displayed onstage for laughs. The political message the Senior Follies intended for its audiences therefore had to be filtered through a revue format that promised laughs and spectacle but not necessarily serious contemplation.

The Oklahoma Senior Follies is modeled after the famed Follies created by Florenz Ziegfeld. Essentially a musical revue, the Ziegfeld Follies featured a variety of musical numbers, dance routines, and some of the most beautiful women to ever appear onstage, all exotically (and erotically) dressed. Often plumed in flowing, sequined gowns and elaborate headdresses, these Ziegfeld Girls came to establish the showgirl as an American stage icon. Ziegfeld's productions often were frivolous and seedy entertainment, and the revue format allowed a great deal of flexibility and innovation because of its low mark in artistic ambition. Choreography and musical numbers could change on a whim, and often did, in order to meet the last-minute demands of the production's exacting impresario. The musical material needed to be as flexible and interchangeable as the delicate fabrics draped over the bodies on display, and for that reason what survives of the music featured in Ziegfeld's Follies is limited. ${ }^{20}$ A variety show need not be in the service of an archive, of course. As Michael Lasser, the charming moderator of the well-known radio show Fascinatin' Rhythm reminds us, "A revue makes no claim on dramatic literature. It is theater pure and simple. .. . No one ever sits down to read a revue." Lasser goes on to press his point further: "No one ever studies one as you might a play. No one ever revives one[,] because they are, by definition, topical and occasional."21

The occasional, provocative, and jesting nature of Ziegfeld's Follies makes for a complex medium to display the vitality and presence of an aging population. On the one hand, the musical revue format Ziegfeld popularized celebrates frivolity and immediacy, aspects easy to brush off and underestimate. On the other hand, musical revues defy 
codification. Portions of the show can simply be transplanted or completely restructured from year to year, city to city, even show to show. For the Senior Follies, this loose-fitting format allows for local concerns and societal habits to infuse readily into an evening billed as harmless lowbrow entertainment. Indeed, the very medium through which the decline narrative is combated on these stages allows for the message to carry beyond the auditorium. Still, audiences are expected to decipher the important message-if they even are searching for one-amid the codes of an entertainment format that inherently resists the solemn or austere.

The adaptation of Ziegfeld's sexual provocations is a case in point. Most, if not all, of the Senior Follies productions devote significant time to displaying an aged version of Ziegfeld Girls, or "Beauties," as the Oklahoma Senior Follies called them, through an elaborate and spectacular pageant of elderly women dressed in outlandish outfits. In the Oklahoma Senior Follies, the Beauties were a major selling point. Indeed, these women have been and continue to be the image of the Senior Follies marketing campaign each year. All of the print and digital publicity art features a close-up image of a smiling, attractive woman bespangled in a huge feathered headdress and glittering gown. The colorful leotard is cut low in the back and high around the thigh. Beads, brocades, and mesh hosiery all signify the iconic showgirl of yesteryear. At first glance, one might never have guessed the model was a great-grandmother who had survived two husbands. The tight-fitting clothes and heavy stage makeup are part of a calculated and witty plot twist in the standard story of growing old that nonetheless sits uneasy with audience members. Are audiences supposed to see these Beauties as sexually provocative, as they were meant in Ziegfeld's productions, or are the Beauties meant to be understood as cultural enactments that challenge stereotypes about the aging body and beauty? Implying elegance and beauty in old age is one thing, but the Ziegfeld context asks audiences to see these women as sex objects, sending mixed signals about where value in the maturing body ought to be placed.

The Senior Follies movement may attempt to disassociate aging from decline, but the musical and dramatic structure of the revue format forces performers to make claims about aging through slapstick comedy, often at their own expense. I remember one production where otherwise-abled (and remarkable!) tap dancers performed a routine in wheelchairs while wearing adult diapers. Another year, two local comedians danced a striptease-gone-wrong to a bossa nova-inspired rendition of "Tea for Two." As the routine went on and the paper cutouts that covered the women's tops and bottoms increasingly and-as the joke suggesteduntantalizingly got smaller and flimsier, the audience was treated to a rather frank reveal, only to be relieved by a perfectly cued blackout at 
the end. That same show, six men and women performed a version of "Friendship" — made popular in the 1962 revival of Cole Porter's Anything Goes - that included a refrain mimed without any teeth. Sprinklings of jokes about impotence, incontinence, and menopause broke up more sanguine moments about the condition of empty-nesting or sentiment for times past.

The Ziegfeld format is largely why the Senior Follies has found momentum; it provides an effective platform in part because people don't expect to take it seriously. Annette Martin told me "the three Fs" that make up her litmus test for material in her shows: "Fast, Funny, Familiar-everything in the show must have at least one of these characteristics," adding her observation that seniors are willing to be laughed at, whereas people in other generations "would just die." 22 It was clear from my experience with the Oklahoma Senior Follies that for most of the cast, getting laughs was a highlight of the entire show. After all, the Follies cast was only pretending to be decrepit. The performers were still able-bodied and socially active and were simply donning a character type that both brings attention to matters of interest to the aging population and gets easy laughs at the expense of those some sociologists have called the "old-old." The performers' willingness to engage in often demeaning or self-defeating antics through the musical stage makes the Senior Follies as much a form of minstrelsy as a means for challenging ageist assumptions. This is perhaps a weakness of the Ziegfeld model, since the format encourages audiences to respond with laughter rather than contemplation. Still, the opportunity to take ownership of inevitable bodily deterioration or personal loss and spin it positively as just one aspect of an otherwise viable and potentially blissful phase of life likewise positions the Senior Follies as one of the few places where matters of aging become refocused as things that do indeed matter and where audiences can learn to recognize the decline narrative as a farcical, rather than a purely essentializing, part of modern society.

This strategy mirrors the way in which recent approaches to disability favor acceptance over unrealistic overcoming narratives, recognizing that with acceptance can come the capacity to celebrate that acceptance, thereby creating a space where other possibilities can be imagined. In fact, it is helpful to see the work of the Senior Follies as contributing to a dialogue on disability. The decline narrative already suggests a certain framework of bodily and cognitive disability not lost on the Follies personnel-indeed, the stage director for the Oklahoma Senior Follies was legally blind. But the case goes deeper than that. Various incarnations of ageism have pushed aging employees out of work (or, in the case of musical theater, off the stage, as will be discussed in the next section) and imagined apocalyptic fears about a growing population of inept and dependent elders feeding off the efforts of younger, employed 
populations. Ageism also pushes rhetoric of isolation and humiliation similar to the separate but equal policies of the Jim Crow era. Through systematic ousting from employment or exile to retirement centers and nursing homes, the aging have been removed from neoliberal-defined "meaningful" positions, disabled from prioritized interactions, and withheld from conversations of value.

\section{"There Weren't Roles for People like Me"}

One can look to Oklahoma City's history of theater to better understand how aging performers there came to be devalued in and displaced from the musical stage. Since 1963 Lyric Theatre of Oklahoma has been the state's "leading professional theater" and a prized gem in Oklahoma City's crown. ${ }^{23}$ The peculiar politics of the state and the simmering rivalry between the two largest cities-Oklahoma City and Tulsa-play out on even the slightest of battlefields, musical theater included. In the arena of professional theater, however, Oklahoma City hit its stride first. It would be another twenty years before Tulsa's Gilbert and Sullivan Society would be created, an organization that would later evolve into Light Opera of Oklahoma (LOOK) and, as of 2012, LOOK Musical Theatre. The Tulsa company's recent and abrupt cancellation of its 2015 summer season, however, is but the latest struggle in the theater's history. Lyric Theatre of Oklahoma, on the other hand, continues strong, living up to its own mission "to enrich the quality of life for the people of Oklahoma." Lyric has even garnered some national accolades in its fifty-year history. Not long ago, USA Today named the theater one of the "10 great places to see the lights way off Broadway." 24

Lyric Theatre has had to evolve along the way to meet such success. The two largest adaptations occurred within recent memory. The first was the 2002 move from the vintage Kirkpatrick Theater on the uptown campus of Oklahoma City University to the newly restored Civic Center Music Hall near downtown. The Civic Center renovation was part of a larger capital improvement campaign known as MAPS (Metropolitan Area Projects), which, following the devastation of the bombing of the Alfred P. Murrah Federal Building in 1995, became the necessary means for the city to rebuild and rebrand itself. Moving Lyric Theatre's productions into the Civic Center was not just about showcasing a newer and bigger space. The Civic Center became an emblem of Oklahoma City's cultural renaissance, its determination to move past its dusty stockyard image. Displaying talent on that stage every summer linked Oklahoma City's commitment to the arts with a commitment to its identity as a city coming into its own.

Who exactly was in that talent pool was the question at the heart of the second adaptation. For its first three decades, Lyric Theatre functioned 
more or less as a professionalized community operation. "Lyric was a glorified community theater," one former cast member told me, "but professional in that we got paid. It was kind of like our summer camp." 25 Local performers cut their teeth on the Kirkpatrick stage. Leading roles in the summer musicals mostly went to local actors, and the ensemble was almost entirely made up of local college students. Like many regional theaters at the time, Lyric Theatre was not affiliated with any actor or stage manager unions and thereby kept expenses down. Its reputation as a nonequity theater likewise made for an abundance of opportunities for local performers and audiences to connect without the mediation of megacorporate sponsorship or prohibitively high ticket prices. As one Senior Follies cast member remembered, "We didn't have to have corporate sponsors. It was just done." 26

This all changed in the mid-1990s when Lyric Theatre became an equity theater and began "farming out all the principal roles" to equity holders. ${ }^{27}$ It takes a great deal of theatrical exposure and experience in the right kind of roles and in the right kind of theaters for an actor to get his equity card; this is but one reason why most equity members live not in the tree-lined suburbs of Oklahoma City but among the bustling boroughs of Manhattan. The effect, of course, is that fewer roles are now available for those once-active Oklahoma City performers. Instead, audiences have become trained to recognize great talent by its accompanying New York pedigree. Out-of-town performers book three-to-four-week gigs in small companies like Lyric Theatre before moving on to the next regional theater. This puts pressure on local theaters to bring in experienced stage directors, musical directors, set designers, lighting designers, sound designers, and choreographers from New York to further entice Broadway talent to come to these smaller communities. It is still customary to stock the ensemble with local college or high school students willing to work for cheap, but in almost every other way regional theaters like Lyric Theatre have adapted their way out of local theater and instead have become the primary mediator between Broadway talent and regional audiences.

Theatrical spaces have long been a site of negotiations between classes, races, and politicized bodies, as Lawrence Levine convincingly argued in his often-quoted book Highbrow/Lowbrow. ${ }^{28}$ Significantly, these negotiations were handled by a mixture of both lay and professional actors. Pageantry, perhaps the most pronounced and prominent of these local theatrical traditions, offered locals the opportunity to enact the history of their particular place and people - to help "explain the city to itself," as David Glassberg put it - even though those dramatizations were organized and directed by professional pageant-masters from New York or Boston. ${ }^{29}$ Particularly in the years between the American Civil War and World War I, community theater traditions like pageantry provided 
Americans a dramatic platform for issues of local importance; even productions by professional touring troupes were subject to regional fluctuations in ideologies or political commitments. In her book Local Acts, Jan Cohen-Cruz fleshes out the rich and complex history of nonprofessional theater in the United States: "The basic unit of [community-based performances] is the people who contribute to it through their stories or their co-creation as performers, people who are intimately connected to the theme of a given production via lived experience, which is facilitated but not replaced by professionals. Community-based performance will always offer a first-voice account of a situation that most professional art does not." 30 Thus, the interplay between professional and amateur performers has traditionally been in the service of local needs. Community theater provided a means of giving voice both to performers seeking validation through the stage and to the audience that came to the theater seeking assurance that there was a place where their lives and treasured ideals still held value.

The actuality of regional musical theater today, however, does not always resemble that ideal. Large, tax-funded spaces like Oklahoma City's Civic Center provide a place for the community to gather, yes, but they also favor large productions of homogenized or generic road shows and national tours. Smaller, local productions can hardly compete with these larger attractions. By moving in to the much larger facility, Lyric Theatre of Oklahoma created a financial scenario that pushed out local performers with the expectation that such a policy would entice more bodies to fill the increase in seats. In doing so, the company has become subject to the whims of corporate giving. Courting corporate sponsors, not consummate artistic ability, has become the necessary skill and a primary job of these theaters' artistic staff.

For the Senior Follies cast members I worked with, this kind of change came at a high cost. Privileging equity holders silenced the voices of not only local but also aging performers. As one performer sadly recounted, "Between 1972 and 1992 I did twenty-five roles — mostly leading roles-at Lyric Theatre. Then all of the sudden they didn't need me anymore. Lyric was like a family, and now it's all very impersonal." 31 Even though many of the Oklahoma Senior Follies cast were not yet "seniors" when Lyric Theatre began casting younger, equity actors, the act of estrangement "aged" the performers out of business and thereby removed an important means by which local performers communicated local matters to local audiences. Gullette's words unfortunately find easy application here: "At no age would anyone be able to say, of being aged by culture, 'Not my issue.' Of no identity could anyone say a priori, 'Aging-in-culture has nothing to do with this.'" 32

In no small way, the voice of locality and of the aging in Oklahoma City lost the means by which it could be valued in the wake of Lyric Theatre's 
restructuring. The consequences for this loss of voice are significant. The impulse for narrating and voicing one's life issues and perspectives is so embedded in human experience, as sociologist Nick Couldry has articulated, that "to deny value to another's capacity for narrative- - to deny her potential for voice - is to deny a basic dimension of human life." 33 Indeed, to lose one's voice is to become not only inaudible but also invisible. I was reminded of the former invisibility of my cast members each night during the show. As conductor, I was made privy to intermission banter among audience members sitting near the orchestra pit, who regularly made a comment along the lines of "I didn't realize there were that many really talented old people in our community," as if glimpsing aging bodies onstage made it suddenly clear how little their absence until then was felt. I have already suggested that the musical theater genre has made little room at the table for aging performers. Combined with the loss of local performing outlets, those aging performers who depended on the musical stage for supplemental income, camaraderie, and opportunities for self-expression found themselves doubly unvoiced.

This is the atmosphere out of which the Senior Follies emerged. "For ten years I didn't perform at all," said one cast member. "[Senior] Follies came along at a really good time for me because there weren't roles for people like me."34 The Oklahoma Senior Follies took a chance on the aging performer population ("people like $\mathrm{me}^{\text {") }}$ the way no other organization had been willing or able to do. Those who had worked in Lyric Theatre's "glory days" were reunited onstage, and audiences who adored them once came out in droves to hear them and cheer them again. Even the choice of venue-Oklahoma City University's beloved Kirkpatrick Theater-seemed designed to redeem older, forgotten qualities of musical theater culture in Oklahoma City. In speaking about performing with the Senior Follies in the Kirkpatrick Theater, a cast member happily reported that, having done so many shows there long ago, "it was like going home."

\section{"Take Me Back to Oklahoma City"}

The Oklahoma Senior Follies was in its third year when I began as musical director. While the Ziegfeld model complicated an easy response to what exactly the aging performers onstage were attempting, the musical structure and arrangements made the point clearer. The basic ingredients for the Follies were rather straightforward: There had to be the right mix of dance numbers, featured soloists, and group songs. Cheeky skits and one-liners were easy to fit in wherever and whenever we needed them. Since the show is built anew each year to meet the needs of changing personnel (in this kind of theater, death is the most dependable of all considerations) and to keep the show fresh and buoyant, the creative 
team had a difficult task of building cohesion into the otherwise scattershot revue format. Particularly in the farcical context of the Ziegfeld format, the challenge was to select stylistically appropriate music that also reinforced the implicit message that aging ought to be celebrated rather than bemoaned.

The solution to that challenge was to make explicit the piecing together of unlike songs and genres through a system of mash-ups. Mash-ups became a sonic emblem of bricolage, to evoke Claude LéviStrauss, helping frame the Oklahoma Senior Follies as a space where old means are reused to achieve new ends. ${ }^{35}$ Our use of mash-ups made the Oklahoma Senior Follies a bit like the inverse of the television series Glee (2009-15), where youth is celebrated and the sexual tension of adolescence is underscored with a musical theater-inspired soundtrack. In Glee, musical theater songs that would normally be prescribed by body type, gender, or race are disassociated from their original context and "mashed" together with pop songs to create a unique narrative device for the show. One pluvial episode, for example, featured a clever overlaying, or "mash-up," of Freed and Brown's iconic "Singin' in the Rain" with Rhianna's "Umbrella." The result, of course, is something like neither Gene Kelly nor Rhianna but a new creation of its own fashion. The same possibilities arose in the Senior Follies. We frequently found opportunity to mash together unrelated songs from disparate genres or time periods - finding commonality among them sometimes only in a single phrase-and create something original. The musical mash-up consequently served as an emblem of the aging population's metamorphosis into something neither old nor young but completely new, bold, and wildly interesting.

Although they functioned as a metastructural metaphor for malleability and value, mash-ups were used selectively, making rooms for conventional, stand-alone songs to be played against onstage hijinks. And, as with most revues, the music was sourced from a variety of styles and periods that bowed to the genteel tastes of our cast and audience. Musical theater standards were common but used inventively-Gershwin's "Let's Call the Whole Thing Off" was once reimagined as the soundtrack accompanying an awkward first date of an old-acting-young couple. One year there were three men with particularly resonate, classically trained voices who sang an arrangement of Bernstein's sailor crooner "Lonely Town" from On the Town that reportedly held the ladies in the audience in rapture. Patriotic and religious songs likewise kept these Bible Belt theatergoers entranced. And in the state of Oklahoma, no other piece of music holds more religious fervency than the official state song, Rodgers and Hammerstein's title number from Oklahoma! (1943). When Oklahomans hear that ascending bass line introduction, they literally jump to their feet, the women wave handkerchiefs high in the air, and the room 
bellows with state pride. Everyone standing knows the song by heart, and we ended every Follies show just like that.

One year, we mashed together "Tiny Bubbles" with Lerner and Loewe's "The Night They Invented Champagne" from Gigi. With a nod toward Hawaiian performer Don Ho's original version, "Tiny Bubbles" was performed as a solo accompanied by ukulele, soft-shoe dancing, and a bubble machine-all reinforcing the connection between "tiny bubbles in the wine" and the sparkling froth of Champagne. Aside from the more obvious textual connection the two songs share, the mash-up was crafted to make a clever statement regarding aging stereotypes. The film-turned-musical Gigi is mostly known for the humorous song "I Remember It Well," after all, which entails an older couple reminiscing about their early courtship, yet neither one can quite remember well enough to get the facts straightened out. Instead, we chose "The Night They Invented Champagne" as a companion to "Tiny Bubbles" in order to frustrate that assumption of decline and pump more bubbly energy into the beginning of the show.

A more poignant moment later in the evening was a mash-up of Frank Sinatra's melancholic "It Was a Very Good Year" with "Let the Sunshine In" from Hair. ${ }^{36}$ The combination of the two seemed opportune. "Let the Sunshine In" is already known as a mash-up of sorts. Its attachment to the song "Aquarius" by the 5th Dimension made it to the top of Billboard's listing of pop singles in 1969 and has led more than a few listeners to hear "Let the Sunshine In" as the ending to the preceding song rather than a separate number altogether. Likewise, the song's six bars of interminable oscillation between major and minor conjure feelings of melancholy or bittersweet, its resisting of easy modal description a comfortable likeness to the Senior Follies penchant for defying convention. I restructured the Sinatra tune to allow time for several of the more prominent cast members to sing their respective ages and harmonized it to better fit the upbeat sixties groove. "It Was a Very Good Year" originally makes a case for happiness at the ages of seventeen, twenty-one, and thirty-five. Our cast sang a canon of more mature age admissions during the mash-up, starting with "when I was seventeen, twenty-one, thirty-five" and so on and ending with a resounding and applauded "eighty-six," the age of our oldest cast member.

Finally, we slightly tweaked the last verse to better fit the ideology of the Senior Follies. Originally, Sinatra croons of the shortened days of old age - "the autumn of my years" - and looks backward as vindication of a life well lived, singing that, back then, "it was a very good year." Instead, the cast pulled out miniature glow sticks, identical to those distributed to the audience upon admission, and pronounced "it is a very good year." The singers overlaid the final bars of the first tune with hums to a slow groove of "Let the Sunshine In." The lights in the 
house dimmed to almost nothing. Hands clutching neon sticks slowly waved back and forth as the tune got louder and then faster, ceasing only upon the interruption of that familiar ascending bass line that got everyone not already standing on their feet in a hurry. The Oklahoma audience sang their beloved state song for the ten thousandth time but now with plastic glow sticks jostling together with handkerchiefs in the air just above their bodies.

While the creative team put a lot of thought into establishing musical and dramatic flow, some of the more interesting moments resulted from the cast taking control over certain musical selections. While rehearsing one afternoon, a cast member jumped out of his seat, pushed me off the piano, and searched for the chords to an old song. As he played and sang the lyrics to "Take Me Back to Oklahoma City," other eyes lit up around the room, and bodies pressed closer. It was clear this was a tune with a history for many of these performers. First introduced in 1967 at the Petroleum Club of Oklahoma City-a place billed as "the club above all clubs" - the song held a great attraction to the locals. ${ }^{37}$ It was penned by an Oklahoman, first of all-the one condition that only somewhat deflated the glory of Rodgers and Hammerstein's beloved song. ${ }^{38}$ Second, many of the performers in the cast were present when it premiered. The Senior Follies cast immediately began making room in the lineup for the song, and "Take Me Back to Oklahoma City" became an anthem for a time and place that no longer existed but that everyone loved to remember well.

Understanding Oklahoma City's tenuous political and economic history helps elucidate why "Take Me Back to Oklahoma City" was so significant to these performers. On April 22, 1889, land unassigned to any tribe in the center of Indian Territory went from unpopulated to a city of ten thousand, literally overnight, in the first of what would eventually be seven land runs. In 1928 oil was discovered under Oklahoma City, beginning a relationship with petroleum companies that has determined the ups and downs of the city over the years. Prosperous periods meant the construction of stately mansions and a growing downtown sector. By the time "Take Me ,Back to Oklahoma City" was first performed in 1967, however, oil prices had plummeted and the city was in a long period of decline. City officials hired Chinese architect I. M. Pei to restructure the city's layout, hedging bets that the redevelopment would anchor downtown as a desirable place to both live and work despite the mass migration of white and middle-class families to the suburbs. The decision seemed well reasoned —any major city that just appeared overnight was bound to have infrastructural issues. Known as the "Pei Plan," the initiative called for the demolition of hundreds of old buildings to make room for more parking structures, office space, and retail development. To become a modern city, Oklahoma City was asked to prune its edges. 
The timing and implementation of Pei's vision proved disastrous, however. The pool of money dried up before the proposed new structures could be built, leaving large patches of vacant lots scattered over Oklahoma City's landscape. The city looked worse than it did before the redevelopment, and Oklahoma City spent the next several decades in economic stagnation, a shell of its one-time glory.

It is natural that "Take Me Back to Oklahoma City" emerged out of this ruinous situation; the song clings to the kind of sentimentality that helps gloss over the present reality and focus on a hopeful version of the past. For the Senior Follies production, the cast rewrote the lyrics to capture the changes in Oklahoma City's character since 1967. A lot had happened in those intervening decades. Horizontal drilling (or fracking) within previously unattainable deposits of natural gas brought an enormous influx of interest and money to Oklahoma City's natural gas companies and thereby to the city itself. The city's MAPS program, responsible for the Civic Center's facelift, also began to dress up downtown Oklahoma City as a place worth living. Amenities like a new NBA team, unique Olympic water training facilities, and a low cost of living have made the city one of the hottest places for entrepreneurs to set up shop. The Senior Follies cast members lived through all these periods of Oklahoma City's development, and the reuse of the song seemed apropos for a city and a group of people in the midst of reinvention.

The song opens with an admission of far-flung travels:

I have seen the lights

Of old Manhattan nights

I have been alone and blue.

San Francisco's fame

Adds attraction to her name;

I have seen that lovely view.

This opening establishes validity for the speaker's opinion, of course. To have gone to New York City and yet remained faithful in one's heart to Oklahoma City is the kind of valor people in this region adore. Even more, though, this opening verse positions the local performers favorably in an otherwise merciless preference for New York performers that the local Lyric Theatre had maintained for so many years. In the context of the Senior Follies, these performers suggest a scenario in which $\mathrm{New}$ York City does not match up to the opportunities of Middle America.

At the refrain, the thrust of the song becomes apparent: loneliness is the prime condition of life in the big city, while friendly community keeps Oklahoma City close to the heart.

Take me back to Oklahoma City

There I long to be 
Way back home in Oklahoma City

Somebody waits for me.

Open spaces, friendly faces:

You'll see,

I'll be

Happier there

Than anywhere.

Take me back to Oklahoma City

Where I'll see again

All the folks in Oklahoma City,

That's where they knew me when.

Though the song continues for a few more verses, these initial verses serve to illustrate how and why the number became so emblematic for the Oklahoma Senior Follies. "Take Me Back to Oklahoma City" remains a viable anthem for these local performers because, like the city finally experiencing the renaissance it planned long ago, the Senior Follies performers enact through the song their own form of determination and resiliency.

This performance of "Take Me Back to Oklahoma City" put a fine point on the seniors' resistance of conventional notions of aging and decline. The sentimental song written when Oklahoma City was in a downturnbut about the time when it wasn't - was refashioned in the Senior Follies to celebrate not a fading memory of the city's past but the actuality of its bright future. The cast rediscovered in the Senior Follies the promise of a voice formerly denied them. The very resonance of their aging voices suggests the future is not written in stone but lies in wait for those willing to believe there is something of value still left in it for them.

Although the Oklahoma Senior Follies sets out to challenge the narrative of decline, the effect is more a renewal of community than a political statement. This renewal happened on two levels: not only did the Senior Follies bring together a group of aging and displaced performers, but it also reinvigorated the spirit of true community theater in Oklahoma City. Other Senior Follies groups likewise sense the performances themselves as a statement about community. "It can never be about one person or one talent," says Annette Martin. "It has to be about a community of talent. It has to be a lot of people doing a lot of different things and becoming basically a microcosm of what the world needs to be." ${ }^{\prime 39}$ Idealistic sentiment is not out of place here. The Senior Follies confirms that old people can have a place on the musical theater stage, that local talent needs a voice of value, and that audiences who "knew them when" need to feel they can know them again, and likewise. 
For the Oklahoma Senior Follies, this idyllic spirit of community succeeds in part because of the particular conditions the local theater culture has constructed. The restructuring of Lyric Theatre of Oklahoma into an equity house served as a watershed in the history of Oklahoma City musical theater. For those local performers who worked with Lyric Theatre prior to its restructuring, the Senior Follies has been a means of reuniting old friends and providing a musical-theatrical space where aging is performed as an asset rather than a liability. If the Senior Follies continues and eventually becomes populated by performers who have never experienced the nonequity days of Lyric Theatre, that sense of community may lessen or at least change. For now, though, the Oklahoma Senior Follies is succeeding both as a remedy to an industry unresponsive to the conditions of aging performers and as a framework on which local performers have been able to reclaim their voice and, in certain ways, their identity.

The Oklahoma Senior Follies therefore has found a way for aging performers to redeem value in the marketplace of worth, a strategy that problematizes the conveniently drawn line between productivity and old age. By putting senior needs and lives center stage, these performances of decline demonstrate the theatricality of aging and the graceful way some have chosen to establish the power of local voices. Aging bodies and voices may still look for validation today, but the rise of the Senior Follies across the country suggests that an entirely new way of thinking lies just over the horizon.

\section{NOTES}

1. While beyond the scope of this essay, a larger study of aging in musical theater should take into account the particular and gendered space carved out by aging female performers. Mitchell Morris writes of the diva that she is "a woman who struggles to overcome ineradicable marks of a stigmatized identity. . . To become a goddess, she must first appear as a victim" (The Persistence of Sentiment: Display and Feeling in Popular Music of the 1970s [Berkeley: University of California Press, 2013], 170). Aging may be one of those stigmas the diva displays; age is almost always a condition of the diva, marking not only her tenure onstage but also her persistence in spite of increasing years. The role of the diva is thus a calculated performance in itself, often contrived to play into the pathos of hard-won success.

More specifically, Sam Baltimore has written on the peculiarities of both Elaine Stritch's and Bea Arthur's one-woman shows. He argues that Elaine Stritch at Liberty relied on a caricatured version of the diva, where Stritch could "integrate her songs into a life story" featuring the character of "Elaine Stritch herself." In contrast to this perceived comprehensiveness, Arthur's show was heavily mediated. She "presents her songs as miniature dramas in and of themselves, contained moments of acknowledged staginess with rarely any connection to a specific personal emotion or narrative." Baltimore suggests Arthur thus uses her songs "to erect yet another wall of pretense between her fragile self and [the audience's] dangerous attention" (“'Do It Again': Comic Repetition, Participatory 
Reception and Gendered Identity on Musical Comedy's Margins" [PhD diss., University of California, Los Angeles, 2013], 142). In both cases, the aging performers find comfort in these contrivances: between Stritch's reenactment of her self-fashioned character's life and Arthur's selective fashioning of her life onstage, the audience is kept at arm's length from the performers and, in my estimation, from the admission of age itself.

2. Ted Neeley starred as Jesus in the 1973 film version of Jesus Christ Superstar and subsequently performed that role over a thousand times. In 2010 he returned to the stage as Jesus at the Fox Theater in Riverside, California. See Jasmine Regala and Pamela Hogan, "A Conversation with Ted Neeley," Fox Riverside Live!, April 9, 2010.

3. Raymond Knapp, "'Waitin' for the Light to Shine': Musicals and Disability," in The Oxford Handbook of Music and Disability Studies (New York: Oxford University Press, 2015), 815.

4. There are many examples of musical theater's display of progressive themes. As a small sampling, consider the treatment of interracial marriage in Show Boat (1927), homosexuality in A Man of No Importance (2002), or, recently, the color-blind casting of historical characters in Hamilton (2015).

5. Margaret Morganroth Gullette, Aged by Culture (Chicago: University of Chicago Press, 2004), 138.

6. Annette Martin, phone interview with the author, June 16, 2015.

7. Still Kicking: The Fabulous Palm Springs Follies, directed by Mel Damski (1997, Palm Springs International Short Film Festival).

8. Bobbie Burbridge Lane, email correspondence with the author, June 16, 2015.

9. Jim Henline, phone interview with the author, June 17, 2015.

10. Michael Mangan, Staging Ageing: Theatre, Performance and the Narrative of Decline (Chicago: University of Chicago Press, 2013), 8.

11. "Elder Stereotypes in Media and Popular Culture," www.agingwatch.com (accessed August 14, 2015).

12. Lisa Kennedy, "Movies and TV: Popular Culture Is Giving Old-Age a Fresh Look," Denver Post, February 1, 2013.

13. Gullette, Aged by Culture, 101.

14. Ibid., 11.

15. Mangan, Staging Ageing, 21.

16. Gullette, Aged by Culture, 135.

17. See, for example, Victor Turner, "Liminality and Communitas," in The Ritual Process:

Structure and Anti-structure (New Brunswick, NJ: Aldine Transaction Press, 2008).

18. Mangan, Staging Ageing, 73.

19. Martin interview.

20. Ann Ommen van der Merwe has constructed a much-needed history of the Ziegfeld Follies despite this lack of source material. Still, in her introduction she discusses the inherent limitations from a frustratingly incomplete archive: "Due to the transient nature of material in the Follies, there is no such thing as a definitive version of any annual production. One can only piece together a representative version of each Follies production, a version that is necessarily based on those source materials that survive" (The Ziegfeld Follies: A History in Song [Plymouth, UK: Scarecrow Press, 2009], xiii).

21. Michael Lasser, "The Glorifier: Florenz Ziegfeld and the Creation of the American Showgirl," American Scholar 63, no. 3 (Summer 1994): 441.

22. Martin interview.

23. "Mission and History" on Lyric Theatre of Oklahoma's website, http://www.lyrictheatreokc .com/about-the-lyric/mission-and-history (accessed August 11, 2015).

24. "10 Great Places to See the Lights Way Off Broadway," USA Today, July 14, 2005, http://usatoday30.usatoday.com/travel/destinations/10great/2005-07-14-regional -theaters_x.htm (accessed August 11, 2015). 
25. Christy Carson, phone interview with the author, June 17, 2015.

26. Henline interview.

27. Carson interview.

28. See Lawrence Levine, Highbrow/Lowbrow: The Emergence of Cultural Hierarchy in America (Cambridge, MA: Harvard University Press, 1990).

29. For his extended analysis of this phenomenon, see David Glassberg's chapter, "To Explain the City to Itself," in American Historical Pageantry: The Uses of Tradition in the Early Twentieth Century (Chapel Hill: University of North Carolina Press, 1990), 157-200.

30. Jan Cohen-Cruz, Local Acts: Community-Based Performance in the United States (New Brunswick, NJ: Rutgers University Press, 2005), 26.

31. Henline interview.

32. Gullette, Aged by Culture, 38.

33. Nick Couldry, Why Voice Matters: Culture and Politics after Neoliberalism (London: SAGE Publications Ltd., 2010), 7.

34. Carson interview.

35. See Claude Lévi-Strauss, The Savage Mind (Chicago: University of Chicago Press, 1966).

36. "It Was a Very Good Year" was recorded by Sinatra for inclusion in his 1965 album September of My Years. Released in anticipation of Sinatra's fiftieth birthday, the autumnal album includes other similarly age-tinted songs, including arranger Gordon Jenkins's "How Old Am I?" and Harold Arlen's "Last Night When We Were Young."

37. www.petroleumclubokc.com (accessed August 14, 2015).

38. "Take Me Back to Oklahoma City" was written and first performed by John Curry. To my knowledge, no recording of the song was ever made.

39. Martin interview. 